\title{
Blood biochemical changes in common carp (Cyprinus carpio Linnaeus, 1758) fed different levels of copper sulphate and zeolite
}

\section{Arzu Aydın Uncumusaoğlu*}

Departments of Environmental Engineering, Faculty of Engineering, Giresun University, 28200 Giresun, Turkey

\section{A R T I C LE IN F O}

\section{Research Article}

Received 17 October 2017

Accepted 13 November 2017

Keywords:

Common carp

Copper exposure

Heavy metal contamination

Fish biochemistry

Blood analysis

Clinoptilolite \begin{abstract}
A B S T R A C T
In this study, copper toxicity, was investigated after the addition of zeolite to the diet of common carps (Cyprinus carpio). The experiment included four groups with three replicates each. The 4 group feeds were $\left[\mathrm{CuSO}_{4} ; \mathrm{CuSO}_{4}+\right.$ Zeolite; Zeolite, and the control without $\mathrm{CuSO}_{4}$ or Zeolite with three replicates each. Fishes were kept in $80 \mathrm{~L}$ glass aquariums with 10 fishes with a mean weight of $60.6 \pm 0.2 \mathrm{~g}$. At the end of each period, a necropsy was performed on fishes from each treatment, and gross clinical signs were recorded. We found significant changes in the blood parameters of the common carps with or without different levels of zeolite and copper. Changes in cholesterol (CHOL), triglyceride (TG), low density lipoprotein (LDL), alanine aminotransferase (ALT), aspartate aminotransferase (AST), alkaline phosphatase (ALP), calcium $\left(\mathrm{Ca}^{2+}\right.$ ), phosphorus $\left(\mathrm{P}^{+}\right)$, sodium $\left(\mathrm{Na}^{+}\right)$, potassium $\left(\mathrm{K}^{+}\right)$, chloride $\left(\mathrm{Cl}^{-}\right)$, magnesium $\left(\mathrm{Mg}^{2+}\right)$, and ferrous $\left(\mathrm{Fe}^{+2}\right)$ were also significant. Our results suggest that zeolite can be used in fish feeds at a rate of $40 \mathrm{mg} / \mathrm{l}$ to mitigate the toxic effects of copper.
\end{abstract}

\begin{tabular}{l} 
*Corresponding Author: \\
\hline E-mail: arzu.a.uncumusaoglu@gmail.com
\end{tabular}

DOI: https://doi.org/10.24925/turjaf.v6i1.01-06.1651

\section{Introduction}

Increasing industrial, agricultural and commercial activities leads to severe ecological problems and affect the organisms living in the polluted environments (Kanyılmaz et al., 2014; Kanyılmaz and Tekellioğlu, 2016). Organisms living in terrestrial and aquatic environments are often exposed to heavy metal pollution that sometimes because causing serious health problems such as cancer. Since heavy metals are not biologically degradable, they accumulate within the tissues of living creatures (Olmedo et al., 2013). Copper is one of the most important heavy metal pollutants that affect aquatic organisms (Mazon et al., 2002). Many researchers emphasized that exposure to copper reduces body weight in fish (Schjolden et al., 2007) and inhibits digestive enzymes and lipase (Sastry and Gupta, 1978). It has also been shown that copper toxicity caused renal malfunction, anaemia, brain and liver damage, cancer, hyperactivity, and general psychological impairment in humans (Salim et al., 2003).

About 40 zeolites formed by interlinks with alumina tetrahedra $\left(\mathrm{AlO}_{4}\right)$ and silica $\left(\mathrm{SiO}_{4}\right)$ occur naturally. Zeolites have been used as feed additives in diets of aquatic animal diets to mitigate the effects of heavy metal toxicity in aquaculture. Clinoptilolite, bentonite, modernite and sericite were added to diets of many fish species such as Coho salmon, Oncorhynchus kisutch (Edsall and Smith, 1989), Rainbow trout, Oncorhynchus mykiss, (Obradović et al., 2006), European sea bass, Dicentrarchus labrax (Dias et al., 1998), Common carp, Cyprinus carpio (Khodanazary et al., 2013; Mutlu, 2016), Tilapias, Oreochromis niloticus and Tilapia zilli (Y1ldırım et al., 2009) and Shrimp, Litopenaeus schmitti (Galindo et al., 2006).

The addition of clinoptilolite to diets of animals seemingly increased total yields in aquaculture, poultry and in treatment of certain farm animal diseases (Karamanlis et al., 2008; Papaioannou et al., 2005). Moreover, it improved quality products and reduced bacterial contamination in carps (Tepe et al., 2004) and in mice (Martin-Kleiner et al., 2001). Although the natural and synthetic zeolites are commonly used in industry, agriculture, animal husbandry and environmental protection, there are not sufficient studies on their effects in appropriate animal models and possible medical applications (Martin-Kleiner et al., 2001).

Many studies were conducted to investigate the interaction between heavy metal concentrations and biomarkers (Lushchak, 2011) but only a few are related to 
blood biochemical changes in fish in the presence of heavy metal and zeolite. The present study that was determined the effects of zeolite and on blood biochemical parameters of common carp exposed to copper sulphate.

\section{Materials and Methods}

The study was carried out by the Fisheries Faculty of Kastamonu University. The experiments were performed with in $80 \mathrm{~L}$ glass aquariums with a temperature of $23.5 \pm$ $1^{\circ} \mathrm{C}, 8.0-8.3 \mathrm{pH}$ and lasted for 90 days.

Before starting the experiment, the fish were acclimated for 15 days [Repetition]. The hardness of the water varied between 212 and $216 \mathrm{mg} / \mathrm{CaCO}_{3}$. While alkalinity varied between 218 and $222 \mathrm{mg} / \mathrm{l} \mathrm{CaCO}_{3}$. The dissolved oxygen in the water varied between $6.2 \mathrm{mg} / \mathrm{l}$ and $6.5 \mathrm{mg} / \mathrm{l}$. All the aquariums were supplied with pure oxygen. The amount of dissolved oxygen decreased in the last 15 days compared to the first weeks. The water was recycled from through a $0.22 \mu \mathrm{m}$ automated filter system. The fish were fed with extruded granular pellets. Each aquarium was filled with fresh water and stocked with 10 common carps that were fed $2 \%$ of their initial weight. Twelve aquariums were kept on 16 hours light and 8 hours dark. Natural zeolite (clinoptilolite) used in the experiment were obtained from a private company (Izmir, Turkey). The chemical composition of the used zeolite is given in Table 1.

A total of 120 common carps (mean weight of $60.6 \pm$ $0.2 \mathrm{~g}$ ) were divided in four experimental groups with three replicates each. The experimental groups and their properties are shown in Table 2. The feed of group A was supplemented with $5 \mathrm{mg} / \mathrm{l}$ copper sulphate $\left(\mathrm{CuSO}_{4}\right.$ $\left.\left(5 \mathrm{H}_{2} \mathrm{O}\right)\right)$. That of group $\mathrm{B}$ with copper sulphate $(5 \mathrm{mg} / \mathrm{l}$ $\left(\mathrm{CuSO}_{4}\left(5 \mathrm{H}_{2} \mathrm{O}\right)\right)$, zeolite $(40 \mathrm{mg} / \mathrm{l})$. The feed of group included only zeolite $(40 \mathrm{mg} / \mathrm{l})$ and group D (control) included neither zeolite nor copper sulphate. At the end of each period (30th, 60th and 90th day), all fishes from each treatment were checked for gross clinical signs.

Table 1 Chemical composition of used zeolite (Izmir, Turkey)

\begin{tabular}{l|c}
\hline \multicolumn{1}{c|}{ Component } & Weight, \% \\
\hline $\mathrm{Al}_{2} \mathrm{O}_{3}$ & 11.84 \\
$\mathrm{Fe}_{2} \mathrm{O}_{3}$ & 1.47 \\
$\mathrm{MgO}$ & 1.15 \\
$\mathrm{SiO}_{2}$ & 67.11 \\
$\mathrm{~K}_{2} \mathrm{O}$ & 3.44 \\
$\mathrm{CaO}$ & 2.18 \\
$\mathrm{Na}$ & $\mathrm{O}$ \\
$\mathrm{Moisture}$ & 0.38 \\
\hline
\end{tabular}

Table 2 Characteristics of experimental groups (three replicates)

\begin{tabular}{l|ccc}
\hline & $\mathrm{CuSO}_{4}\left(5 \mathrm{H}_{2} \mathrm{O}\right)^{1}$ & Zeolite $^{2}$ & Common crap $^{3}$ \\
\hline Group A & $\mathbf{X}$ & & $\mathbf{X}$ \\
Group B & $\mathbf{X}$ & $\mathbf{X}$ & $\mathbf{X}$ \\
Group C & & $\mathbf{X}$ & $\mathbf{X}$ \\
Group D & & & $\mathbf{X}$ \\
\hline
\end{tabular}

${ }^{1} \mathrm{CuSO}_{4}\left(5 \mathrm{H}_{2} \mathrm{O}\right)(5 \mathrm{mg} / \mathrm{l}),{ }^{2}$ Zeolite $(40 \mathrm{mg} / \mathrm{l}),{ }^{3}$ Common crap (Ten individual fish per aquarium)
Blood samples were collected on a monthly basis from the caudal fin with a syringe and the samples centrifuged at $4000 \mathrm{rpm}$ for $10 \mathrm{~min}$ with Vitros System Chemistry 350 and subjected to biochemical analysis to determine cholesterol (CHOL), triglyceride (TG), low densities of lipoprotein (LDL), alanine aminotransferase (ALT), aspartate aminotransferase (AST), alkaline phosphatase (ALP), calcium $\left(\mathrm{Ca}^{2+}\right)$, phosphorus $\left(\mathrm{P}^{+}\right)$, potassium $\left(\mathrm{K}^{+}\right)$, sodium $\left(\mathrm{Na}^{+}\right)$, ferrous $\left(\mathrm{Fe}^{+2}\right)$, chlorine $\left(\mathrm{Cl}^{-}\right)$and magnesium $\left(\mathrm{Mg}^{2+}\right)$ values. Each test was carried out with four replicates).

Variance analyses were used to analyse the data and followed by Duncan's test with a SPSS package program. A value of $\mathrm{P}<0.05$ was considered significant.

\section{Results}

There were no significant differences in the initial with fish weight, but the final weights differed (Table 3 ) $(\mathrm{P}<0.05)$. Fish consumed their feed, voluntarily at the beginning of the study in all groups. After the $74^{\text {th }}$ day, the fish in Group A was reluctant to eat. This caused significant $(\mathrm{P}<0.05)$ differences in weight gains. In the presence of Zeolite, fish grew better compared to the other groups (Table 3).

Significant differences were observed between treatment groups related to all the studied blood biochemical parameters, cholesterol (CHOL), triglyceride (TG), low density lipoprotein (LDL), alanine aminotransferase (ALT), aspartate aminotransferase (AST), alkaline phosphatase (ALP), calcium $\left(\mathrm{Ca}^{2+}\right)$, phosphorus $\left(\mathrm{P}^{+}\right)$, potassium $\left(\mathrm{K}^{+}\right)$, sodium $\left(\mathrm{Na}^{+}\right)$, ferrous $\left(\mathrm{Fe}^{2+}\right)$, chlorine $\left(\mathrm{Cl}^{-}\right)$and magnesium $\left(\mathrm{Mg}^{2+}\right)$ values $(\mathrm{P}<0.05)$. Changes in blood LDL, $\mathrm{Ca}^{2+}, \mathrm{P}^{+}, \mathrm{Na}^{+}, \mathrm{K}^{+}$and $\mathrm{Cl}^{-}$values are presented in Table 3 and in Figures 1(a-m).

The blood cholesterol (CHOL) value are effective by toxic substances, reproductive, industrial wastes and pollution, diseases, nutritional status, sex, month and seasons, year of fish species (Çelik and Bilgin, 2007). The zeolite is a suppressant for cholesterol level at the end of the first 30 days, with little effect detected for later times (Table 3 and Figure 1a).

The triglycerides (TG) are fatty acid esters of glycerol and are usually found in the presence of more than one type of fatty acid compound. The storage of energy as triglyceride in the fat deposits is very active because triglycerides have high calorific value and low water content. Plasma triglycerides vary with age, sex, and especially with different diets (Çelik and Bilgin, 2007). At the end of 90 days, the value of Group A was lower than the other groups (Table 3 and Figure 1b). In this study, the TG value was not influenced by the zeolite in copper sulphate.

The low-density lipoprotein (LDL) is the major cholesterol-carrying element. Except for the control, the levels of LDL enhanced with time in all the other groups. At the end of 90 days, the highest value was found in Group A (Table 3 and Figure 1c). This suggests that copper sulphate has a positive effect on the LDL. The zeolite also caused the enhancement of LDL levels.

The alanine aminotransferase (ALT), the first sign of damage to the liver is in the enzymes secreted into the blood by liver cells and is found mostly in the liver 
(Ulukaya, 2007). At the end of 90 days, the Group B had the highest value while Group A had the lowest. The values almost doubled with time (Table 3 and Figure 1d). Our results suggest that copper sulphate has a negative effect on the ALT value, but no effect of zeolite.

The intracellular enzyme involved in amino acid and carbohydrate metabolism is the aspartate aminotransferase (AST). It is found in the heart, liver, skeletal muscle, and kidney but mostly in the heart. The AST levels change with time (Ulukaya, 2007). At the end of the 60th day, it remained almost constant in all groups. After 90 days, there was an increase in all groups except for Group A (Table 3 and Figure 1e). In this study, the amount of the AST is pressing by copper sulphate.

The alkaline phosphatase (ALP); the main source of ALP is liver and bone. After 90 days, the ALP levels of all groups decreased mainly in Group B (Table 3 and Figure 1f). This suggests that zeolite at first increases the ALP levels but then after 90 days decreased it.

The calcium $\left(\mathrm{Ca}^{2+}\right)$ level in fish blood is regulated because of metabolic events caused by the effects of some substances in the intestine, kidney and bones (Gürdöl and Ademoğlu, 2010). For the first 60 days, the zeolite, which has a reducing effect on calcium, has been removed from its effect within 90 days (Table 3 and Figure 1g). The calcium values in fish blood ranged from 0.200 to 11.00 $\mathrm{mg} / \mathrm{dl}$ (Çelik and Bilgin, 2007). This study's calcium values were found within these limits.

Because of this copper sulphate had a positive effect on the phosphorus $\left(\mathrm{P}^{+}\right)$within 60 days, whereas the inhibitory effect became effective after 90 days (Table 3 and Figure 1h). As a result, the presence of zeolite was found to be positive during the 60th and 90th days, while it caused phosphorus level stress in the first 30 days. Çelik and Bilgin (2007) reported that phosphorus $\left(\mathrm{P}^{+}\right)$ values in fish blood ranged from 1.33 to $7.98 \mathrm{mg} / \mathrm{dl}$. As a result of this experiment, values were obtained above these limits.

According to the sodium $\left(\mathrm{Na}^{+}\right)$analyses performed in groups, the Group A results were found to have a lower sodium value than Group D at the end of 30 days. The copper sulphate, which is a positive effect of sodium for
30 days, is negatively affected after 90 days, resulting in the suppression of the amount of sodium. Group C, sodium level was found to be lower than Group D after 30 days, not significantly changed after 60 days, and almost equal to Group D after 90 days. This resulted in a negative suppression of zeolite for the first 30 days, but no effect after on days 60 and 90 (Table 3 and Figure 1i). The sodium values in fish blood ranged from 61.80 to $264.80 \mathrm{mg} / \mathrm{dl}$ and the mean sodium value was reported as $162.00 \pm 44.330 \mathrm{mg} / \mathrm{dl}$ (Çelik and Bilgin, 2007). In our study, sodium value was determined in the range of these limits.

The Potassium $\left(\mathrm{K}^{+}\right)$interacts with magnesium and calcium ions to contract the heart muscle and function in the nervous system and is necessary for the activation of some enzymes (Gürdöl and Ademoğlu, 2010). At the end of 30 days, groups A, B and C were found to have lower potassium values than group $D$. At the end of the 90th day, all the groups except for Group A both showed an increase and almost same values (Table 3 and Figure $1 \mathrm{j}$ ). This resulted in negative pressure of copper sulphate after 30 days, positive effect after 60 days, and negative strong suppression after 90 days. The result is that zeolite is neutral with potassium. The potassium values ranged from 0.60 to $14.30 \mathrm{mg} / \mathrm{dl}$ in the fish blood (Çelik and Bilgin, 2007), was found to be among the limit values in our study. This result can be reduced in one or two short sentences

The ferrous $\left(\mathrm{Fe}^{2+}\right)$ is an important element in blood structure and plays an important role in haemoglobin production with protein and copper. It also helps enzymes in protein metabolism, thereby increasing the activity of calcium and copper (Mutlu, 2013). At the end of the 30th day, groups $\mathrm{A}, \mathrm{B}$ and $\mathrm{C}$ were found to have a lower ferrous value than Group $D$ and it is particularly noteworthy that Group $\mathrm{C}$ has the lowest value. At the end of the 60th day, there was an increase in almost all groups except Group D. Only the very rapid increase in Group A stopped at the end of 90 days (Table 3 and Figure 1k). It can be said that zeolite suppresses and decreases the amount of ferrous in the first 60 days and the copper sulphate for 90 days.

Table 3 Changes in blood biochemistry values and weight of common carp (Cyprinus carpio) having different levels of $\mathrm{CuSO}_{4}$ and Zeolite during 90 days of experiment.

\begin{tabular}{|c|c|c|c|c|c|c|c|c|c|c|c|c|}
\hline \multirow{2}{*}{$\begin{array}{c}\text { Blood } \\
\text { Parameters }\end{array}$} & \multicolumn{3}{|c|}{ Group A } & \multicolumn{3}{|c|}{ Group B } & \multicolumn{3}{|c|}{ Group C } & \multicolumn{3}{|c|}{ Group D } \\
\hline & 30-day & 60-day & 90 day & 30 day & 60 day & 90 day & 30-day & 60-day & 90 day & 30-day & 60-day & 90 day \\
\hline $\mathrm{CH}$ & 135.23 & 123.40 & 112.80 & 122.17 & 112.67 & 100.90 & 128.83 & 137.93 & 141.63 & 95.53 & 100.10 & 99.57 \\
\hline TRG & 66.60 & 57.30 & 71.40 & 71.83 & 62.33 & 51.63 & 49.90 & 49.43 & 53.97 & 62.40 & 59.97 & 60.03 \\
\hline LDL & 865.00 & 1106.50 & 1366.17 & 907.70 & 975.17 & 1009.87 & 1269.13 & 1463.27 & 1525.27 & 779.47 & 796.00 & 800.10 \\
\hline ALT U/l & 20.22 & 19.35 & 18.14 & 21.15 & 26.95 & 27.25 & 23.87 & 25.25 & 25.70 & 41.12 & 37.08 & 37.09 \\
\hline AST U/l & 128.31 & 121.34 & 115.01 & 152.49 & 149.78 & 148.34 & 148.87 & 155.81 & 155.74 & 210.43 & 205.61 & 206.21 \\
\hline ALP U/l & 465.20 & 483.97 & 497.07 & 417.17 & 422.50 & 428.40 & 426.60 & 418.03 & 420.97 & 387.23 & 393.03 & 393.03 \\
\hline CAL & 7.64 & 8.02 & 7.85 & 7.85 & 8.38 & 8.15 & 7.85 & 8.28 & 8.37 & 8.22 & 8.75 & 8.75 \\
\hline PHS & 7.27 & 7.83 & 6.30 & 9.20 & 9.60 & 8.63 & 8.20 & 9.17 & 8.33 & 11.17 & 11.77 & 11.50 \\
\hline SOD & 140.97 & 154.30 & 148.03 & 195.50 & 200.53 & 195.00 & 150.50 & 164.33 & 161.03 & 210.93 & 202.27 & 202.47 \\
\hline POT & 4.45 & 4.96 & 4.30 & 6.45 & 6.56 & 6.20 & 4.84 & 5.51 & 5.35 & 7.03 & 7.08 & 7.05 \\
\hline CHL & 119.60 & 126.37 & 116.03 & 130.80 & 135.50 & 128.97 & 112.10 & 117.53 & 112.00 & 156.83 & 150.50 & 150.47 \\
\hline MAG & 4.52 & 4.68 & 4.61 & 5.61 & 5.66 & 5.62 & 4.12 & 4.36 & 4.32 & 6.65 & 6.59 & 6.60 \\
\hline FER & 18.13 & 13.23 & 10.00 & 24.33 & 21.43 & 17.63 & 21.63 & 25.03 & 22.50 & 29.53 & 32.53 & 32.93 \\
\hline MG & 20.96 & 18.32 & 16.5 & 15.18 & 39.77 & 33.83 & 30.03 & 26.9 & 63.04 & 57.26 & 51.32 & 46.7 \\
\hline
\end{tabular}

CH: Cholesterol (CHOL) mmol/l, TRG: Triglyceride (TG) mg/dl, LDL: Low Density Lipoprotein (LDL) U/l, CAL: Calcium (Ca) mmol/l, PHS: Phosphorus (P) mmol/l, SOD: Sodium (Na) mmol/l, POT: Potassium (K) mmol/l, CHL: Chloride (Cl) mmol/l, MAG: Magnesium (Mg) mmol/l, FER: Ferrous (Fe) mmol/l, MG: Mean weight $((60.6 \pm 0.2 \mathrm{~g})+\mathrm{X})$ 
a) Cholesterol (CHOL) $\mathrm{mmol} / \mathrm{l}$

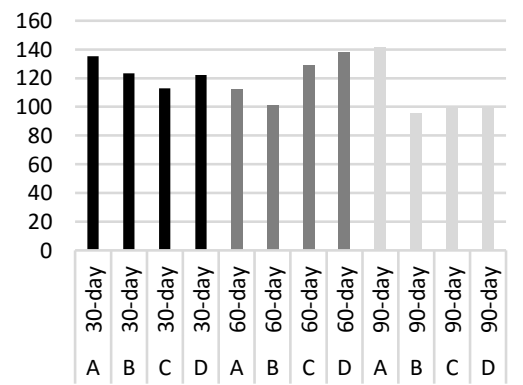

d) ALT U/I

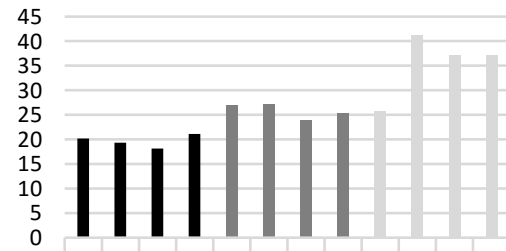

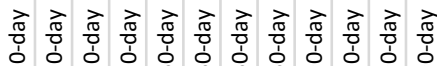

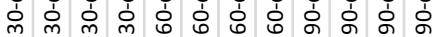
$\begin{array}{llllllllllllll}A & B & C & D & A & B & C & D & A & B & C & D\end{array}$

g) Calcium (Ca) $\mathrm{mmol} / \mathrm{l}$

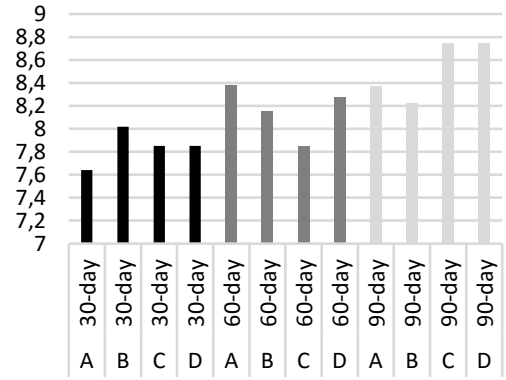

j) Potassium (K) mmol/l

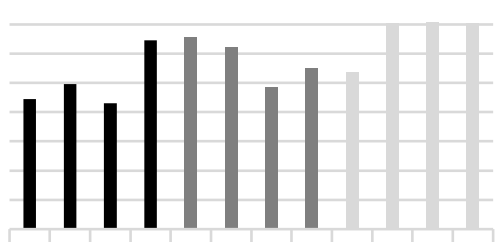

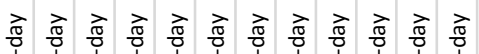
官 \begin{tabular}{l|l|l|l|l|l|l|l|l|l|l|l|} 
A & B & C & D & A & B & C & D & A & B & C & D
\end{tabular}

m) Magnesium (Mg) mmol/l

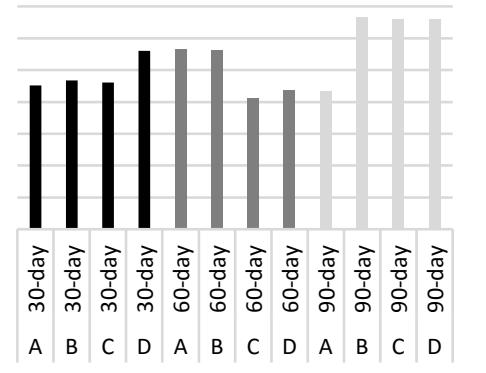

b) Triglyceride (TG) mg/dl

c) Low Density Lipoprotein (LDL) U/I

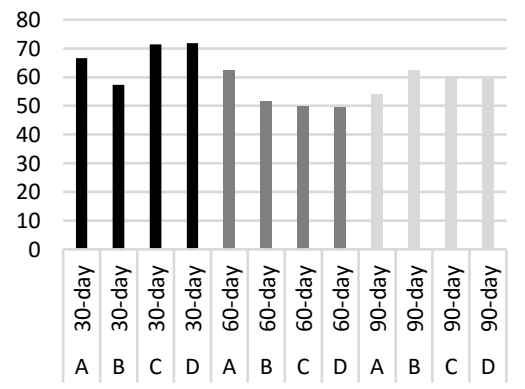

e) AST U/I

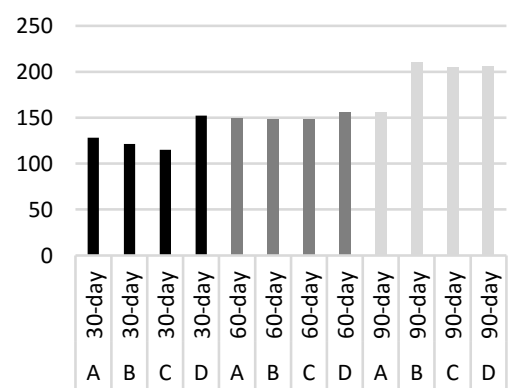

h) Phosphorus (P) mmol/l
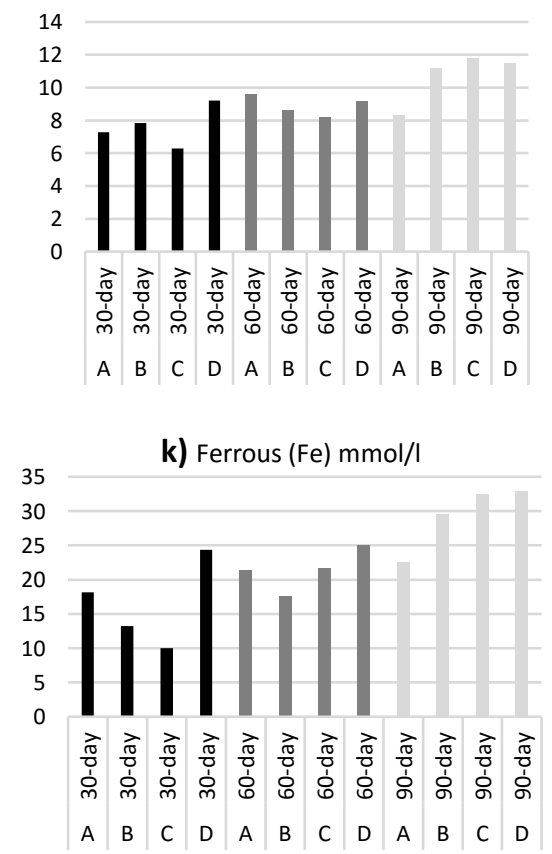

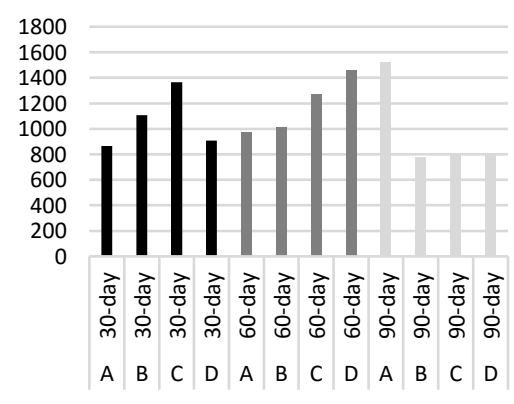

f) $A L P U / I$

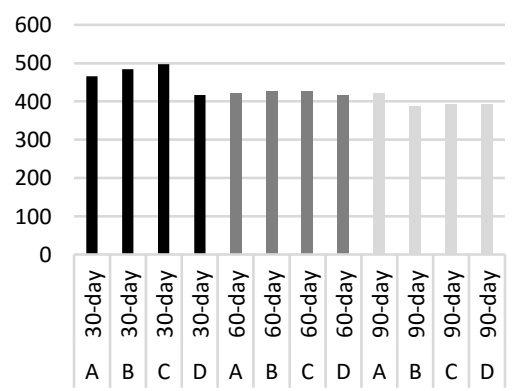

i) Sodium ( $\mathrm{Na}$ ) $\mathrm{mmol} / \mathrm{I}$

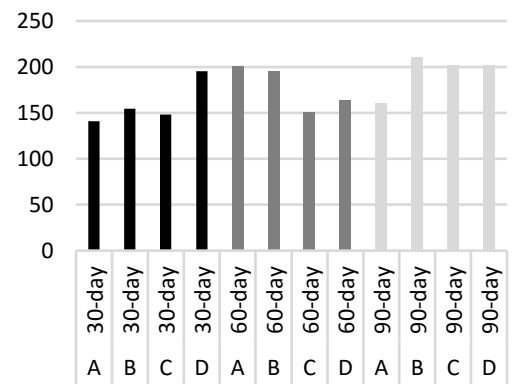

I) Chloride (Cl) $\mathrm{mmol} / \mathrm{l}$

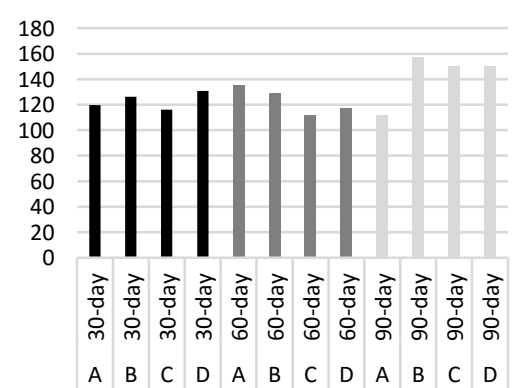

Figure 1a-m Changes in blood CHOL,TG, LDL, ALT, AST, ALP, $\mathrm{Ca}^{2+}$, $\mathrm{P}^{+}, \mathrm{Na}^{+}, \mathrm{K}^{+} \mathrm{Fe}^{2+}, \mathrm{Cl}^{-}$and $\mathrm{Mg}^{2+}$ values of common carp (Cyprinus carpio) having different levels of $\mathrm{CuSO}_{4}$ and zeolite for 30th, 60th, 90th day of the experiment (A: Group A, B: Group B, C: Group C, D: Group D) 
At the end of the 30th day, the amount of chlorine $(\mathrm{Cl})$ Group C was lower than Group D, like groups A and B. After 90 days, the group had the lowest chloride value. This suggests that copper sulphate has a negative effect on the chloride. The zeolite has a negative effect on the chloride level within the first 60 days (Table 3 and Figure 11). The Chloride $\left(\mathrm{Cl}^{-}\right)$values in fish ranged from 73.00$196.00 \mathrm{mg} / \mathrm{dl}$ (Çelik and Bilgin, 2007). In this study chloride, value was found in these limits.

In fish blood, Magnesium $\left(\mathrm{Mg}^{2+}\right)$ values ranged from 1.33 to $7.98 \mathrm{mg} / \mathrm{dl}$ and the mean value was reported as $3.78 \pm 1.020 \mathrm{mg} / \mathrm{dl}$ (Çelik and Bilgin, 2007). The magnesium values obtained in this study were determined within these limits. At the end of 30 days, magnesium levels in all groups are lower than the Group D. Magnesium values were determined at almost the same level in all groups except Group A at the end of 90 days. As a result, copper sulphate had negative effect on the magnesium value within the first 60 days. The negative effect of the zeolite on this parameter at the end of the first 30 days was not detected later (Table 3 and Figure $1 \mathrm{~m})$.

\section{Discussion}

At the end of the 30th day the Group A fish weights, more weight gain was detected than the Group D. At the end of 60th and 90th days, the lowest value is Group D. As a result, it was determined that the copper sulphate caused the biggest effect on weight gain. Using only the zeolite increased in more weight gain than the Group D.

The previous experiments have shown that the zeolite addition into aquatic protects the carp fishes from certain types of heavy metal pollution effects, such as those of lead nitrate (Tepe et al., 2004; Mumpton, 1999). This protective effect is attributed to the high cation capacity of zeolite. As it is known, some of the adverse effects of heavy metal pollution arise from their inhibitory effects on enzyme metabolism. Besides that, it is also known that the cholesterol, lipoproteins, and triglyceride values are connected with the metabolism of lipids and functions of liver and kidney (Yang and Chen, 2003).

Ward et al., (1993) did not find significant effect of zeolite on calcium and phosphorus concentrations of chicken plasma. Conversely, there were significant changes in these values in the present study it was determined that calcium was suppressed by zeolite until the end of the first 60 days. It was observed that especially $\mathrm{Ca}^{2+}$ and $\mathrm{K}^{+}$fluctuated significantly in copper groups. Similar results were reported from a study where zeolite was used (Ward et al., 1991). It has clearly been shown in many researches that the zeolite-added feeds have contributed to the health status, feed efficiency, and growth rates. Moreover, when zeolites are part of the diet, it has been seen that the intestinal disease incident throughout the young animals shows the tendency towards decreasing (Mumpton, 1999).

It was reported that addition of $2-5 \%$ of zeolite into feeds of cattle has led to an increase in body weight and decrease in diarrhea incidence in animals (Mutlu et al., 2016). Considering previous findings and the present data, it can be concluded that using zeolite against copper toxicity may protect fish from many adverse effects of metal. Therefore, further studies are needed in other fish species and at various doses.

Under the lights of these points, it can be concluded from the results obtained in this study that the zeolite treatment used in this research succeeded in protecting fish from many adverse effects. Considering the results obtained in cholesterol (CHOL), triglyceride (TG), low density lipoprotein (LDL), alanine aminotransferase (ALT), aspartate aminotransferase (AST), alkaline phosphatase (ALP), calcium $\left(\mathrm{Ca}^{2+}\right)$, phosphorus $\left(\mathrm{P}^{+}\right)$, sodium $\left(\mathrm{Na}^{+}\right)$, potassium $\left(\mathrm{K}^{+}\right)$, chloride $\left(\mathrm{Cl}^{-}\right)$, magnesium $\left(\mathrm{Mg}^{2+}\right)$, and ferrous $\left(\mathrm{Fe}^{+2}\right)$, it can be easily seen that cholesterol and calcium were suppressed by zeolite until the end of the first 60 days. The presence of zeolite is neutral for TG and ALT and no effect can be identified. Zeolite was found to have a reducing effect only for the calcium value at the end of 60 days. In the presence of zeolite, LDL and ALP values showed an increase after the first 30 days, but this effect was removed in the following periods. The presence of zeolite decreased after the first 30 days for ALT, phosphorus, sodium, magnesium and chloride value, but no effect was detected later. Due to the porous structure of the zeolite, a decrease in the amount of ferrous was detected by the end of 60 days. It might be due to the high cation capacity of the clinoptilolite. All of the alterations observed in ALT, AST and ALP levels in groups throughout the research were obviously due to the addition of zeolite. Similar findings were also reported by previous poultry and fish studies fed diets with varying zeolite levels (Safaeikatouli et al., 2011). In addition, it removes the copper load from the water and therefore decreases the effects of exposure to copper (Tepe et al., 2004).

The results obtained in cholesterol (CHOL), triglyceride (TG), low density lipoprotein (LDL), alanine aminotransferase (ALT), aspartate aminotransferase (AST), alkaline phosphatase (ALP), calcium $\left(\mathrm{Ca}^{2+}\right)$, phosphorus $\left(\mathrm{P}^{+}\right)$, sodium $\left(\mathrm{Na}^{+}\right)$, potassium $\left(\mathrm{K}^{+}\right)$, chloride $\left(\mathrm{Cl}^{-}\right)$, magnesium $\left(\mathrm{Mg}^{2+}\right)$, and ferrous $\left(\mathrm{Fe}^{+2}\right)$ suppressed cholesterol and calcium by the addition of zeolite after the 60 days. The presence of zeolite did not affect TG and ALT. Zeolite reducing reduced the level of calcium value at the end of 60 days. Calcium balances the exchange of liquid electrolyte between the cells in the body and the external environment. The decline in this experiment was likely to continue, it was possible that the fish would be dangerous, but after 60 days the threat was gone. In the presence of zeolite, LDL and ALP increased after the first 30 days, but not after. The presence of zeolite decreased after the first 30 days for ALT, phosphorus, sodium, magnesium and chloride value. Because of these falling values, even the lowest of these values did not pose any threat because the carp is within the tolerance limit. Due to the porous structure of the zeolite (Tepe et al., 2004), a decrease in the amount of ferrous after 60 days. Probably due to the high cation capacity by electron exchange, of the clinoptilolite. Probably due to the high cation capacity of the clinoptilolite. Zeolite the copper load from the water and decreased the effects of exposure to copper (Tepe et al., 2004).

Due to the lack of studies dealt with the exact features and effects of the zeolite minerals, sufficient and detailed discussion and comparisons cannot be done in the present 
time. Therefore, further studies are in need of to figure out biological and biochemical properties and effects of the zeolites in other species.

\section{Acknowledgments}

The author wishes to thank the Ekrem Mutlu for greatly contributed to improvement of the manuscript.

\section{References}

Çelik EŞ, Bilgin S. 2007. Bazi balik türleri için kan protein ve lipidlerinin standardizasyonu, Erciyes Üniversitesi Fen Bilimleri Enstitüsü Dergisi 23(1-2):215-229

Dias J, Huelvan C, Dinis M, Metailler R. 1998. Influence of dietary bulk agents (silica, cellulose and a natural zeolite) on protein digestibility, growth, feed intake and feed transit time in European seabass (Dicentrarchus labrax) juveniles. Aquatic Living Resources, 11(4):219-226.

Edsall DA, Smith CE. 1989. Effects of dietary clinoptilolite on levels of effluent ammonia from hatchery coho salmon, The Progressive Fish Culturist, 51:98-100.

Galindo J, Jaime B, Fraga I, Alvarez JS. 2006. Use of zeolite in White Shrimp Litopenaeus schmitti Feeding. IV Congreso Iberoamericano Virtual de Acuicultura, 106-112.

Gürdol F, Ademoğlu E. 2010. Biyokimya. Nobel Tip Kitabevleri. $2^{\text {nd }}$ Edt., p. 689.

Kanyılmaz M, Koçer MAT, Sevgili H, Pak F, Aydın İ. 2014. Use of natural zeolite for ammonia removal during a simulated live juvenile sea bass (Dicentrarchus labrax) transportation, 6 pages. The Israeli Journal of Aquaculture - Bamidgeh, IJA_66.2014.1027, 6 pages.

Kanyılmaz M, Tekellioğlu N. 2016. Effects of dietary zeolite levels on some blood parameters of gilthead seabream (Sparus aurata) juveniles. Journal of Aquaculture Engineering and Fisheries Research, 2(3):119-127.

Karamanlis X, Fortomaris P, Arsenos G, Dosis I, Papaioannou D, Batzios CA, Kamarianos A. 2008. The effect of a natural zeolite (Clinoptilolite) on the performance of broiler chickens and the quality of their litter. Asian-Aust. J. Anim. Sci., 21(11):16421650.

Khodanazary A, Boldaji F, Tatar A, Dastar B. 2013. Effects of dietary zeolite and perlite supplementations on growth and nutrient utilization performance, and some serum variables in Common carp, (Cyprinus carpio). Turkish Journal of Fisheries and Aquatic Sciences, 13: 495-501.

Lushchak IL. 2011. Environmentally induced oxidative stress in aquatic animals. Aquatic Toxicology, 101(1):13-30, doi:10.1016/j.aquatox.2010.10.006.

Martin-Kleiner I, Flegar-Mestric Z, Zadro R, Breljak D, Janda SS, Stojkovic R, Marusic M, Radacic M, Boranic M. 2001. The effect of the zeolite clinoptilolite on serum chemistry and hematopoiesis in mice, Food and Chemical Toxicology, 39(7):717-72. doi:10.1016/S0278-6915(01)00004-7.

Mazon AF, Monteiro EAS, Pinhero GHD, Fernandes MN. 2002. Hematological and physiological changes induced by sort-term exposure to copper in the freshwater fish, Prochilodus scrofa, Brazilian Journal of Biology, 62(4A): 621-631.

Mumpton FA. 1999. La Roca Magica: Uses of natural zeolites in agriculture and industry. Proceedings of the National Academy of Sciences of the United States of America, 96 (7): 3463-3470.
Mutlu E. 2013. Studies on seasonal (monthly) changes in biochemical parameters of chub (Leuciscus cephalus) living in Kizilirmak basin of Sivas, Atatürk University, School of Natural and Applied Sciences, Department of Aquaculure, Erzurum. (PH. D. Thesis).

Mutlu E. 2016. The effects of lead-induced toxicity on metabolic biomarkers in common carp (Cyprinus carpio l.). Fresenius Environmental Bulletin, 25(5): 1419 - 1427.

Mutlu E, Aydın S, Demir T, Yanık T. 2016. Effect of zeolite and copper sulfate, administered alone and in combination on the biochemical components of blood serum of common carp, Cyprinus carpio. Pakistan J. Zool., 48(6): 1857-1863.

Obradović S, Adamović M, Vukašinović M, Jovanović R, Levic J. 2006. The application effects of natural zeolite in feed and water on production results of Oncorhynchus mykiss (Walbaum). Roumanian Biotechnological Letters, 11(6):30053013.

Olmedo P, Pla A, Hernández A, Barbier F, Ayouni L, Gil F. 2013. Determination of toxic elements (mercury, cadmium, lead, tin and arsenic) in fish and shellfish samples. Risk assessment for the consumers. Environment International, 59:63-72.

Papaioannou D, Katsoulos PD, Panousis N, Karatzias H. 2005. The role of natural and synthetic zeolites as feed additives on the prevention and/or the treatment of certain farm animal diseases: A review, Microporous and Mesoporous Materials, 84:161-170.

Safaeikatouli M, Jafariahangari Y, Baharlouei A. 2011. An evaluation on the effects of dietary kaolin and zeolite on broilers blood parameters, T4, TSH and growth hormones. Pakistan Journal of Nutrition, 10(3): 233-237.

Salim A, Hassasin MA, Zohair A. 2003. A simple procedure or reducing lead content in fish. Journal Food and Chemical Technology, 41(4): 595-597. doi.org/10.1016/S02786915(02)00259-4.

Sastry KV, Gupta PK. 1978. Alteration in the activity of some digestive enzymes by heavy metals and their reversal by a chelating agent. Lead nitrate intoxication, Bulletin of Environmental Contamination and Toxicology, 19(5): 549-555.

Schjolden J, Sorenson J, Nilsson GE, Poleo ABS. 2007. Toxicity of the copper to Crucian carp (Carassius carassius) in soft water, Science of the Total Environment, 384: 239-251.

Tepe Y, Akyurt I, Ciminli C, Mutlu E, Çalışkan M. 2004. Protective effect of clinoptilolite on lead toxicity in common carp (Cyprinus carpio), Fresenius Environmental Bulletin, 13(7): 639-642.

Ulukaya E, 2007. Biyokimya. 3. Baskı, Nobel Yayın Dağıtım. s.536, İstanbul

Yang JL, Chen HC. 2003. Effects of gallium on common carp (Cyprinus carpio): acute test, serum biochemistry, and erythrocyte morphology, Chemosphere, 53(8):877-882.

Yıldırım Ö, Türker A, Şenel B. 2009. Effects of natural zeolite (Clinoptilolite) levels in fish diet on water quality, growth performance and nutrient utilization of Tilapia (Tilapia zillii) fry. Fresenius Environmental Bulletin, 18(9):1567-1571.

Ward TL, Watkins KL, Southern L, Hoyt PG, French DD. 1991. Interactive effects of sodium zeolite A and copper in growing swine growth, and bone and tissue mineral concentrations, Journal of Animal Science, 69(2): 726-733.

Ward TL, Watkins KL, Southern LL. 1993. Research Note: Interactive effects of sodium zeolite A and Eimeria acervulina infection on growth and tissue minerals in chicks. Poultry Science, 72(11): 2171-2175, doi:10.3382/ps.0722172. 